\title{
Comparison of liberal and restrictive blood transfusion: current insights into clinical outcomes
}

This article was published in the following Dove Press journal:

International Journal of Clinical Transfusion Medicine

II October 2016

Number of times this article has been viewed

\section{Merete Gregersen \\ Else Marie Damsgaard}

Department of Geriatrics, Aarhus University Hospital, Aarhus, Denmark

Correspondence: Merete Gregersen Department of Geriatrics, Aarhus University Hospital, P.P. Ørumsgade

II, Building 7, I, 8000 Aarhus, Central

Denmark Region, Denmark

Tel +45 29624147

Email meregreg@rm.dk
Abstract: The aim of this review is to evaluate the evidence of randomized controlled trials and meta-analyses that the current blood transfusion guidelines are based upon. These studies examine the administration of blood to patients where benefits outweigh risks according to the hemoglobin $(\mathrm{Hb})$ level. The guidelines for transfusion policies are based on studies published up to the year 2014 and recommend the restrictive $\mathrm{Hb}$ thresholds as applicable to all care environments compared to a more liberal one. Within the past 2 years, the published studies are more targeted on specific settings and disease groups who can tolerate anemia and who cannot. The recent findings raise the possibility that patient outcome is better using a more liberal transfusion policy in patients with cardiovascular disease and in perioperative patients (surgery for abdominal cancer, cardiac surgery, and frail older patients with hip fracture). There are still many ongoing studies reflecting, what this review also suggests, that the evidence of the restrictive limits used on all patients across the board is not usable for clinicians. In the clinic (as in research), it is crucial to have the opportunity to deviate from the guidelines if signs of anemia are present in the patients and to tailor the transfusion strategy to each patient. There is also a lack of evidence on the most optimal transfusion threshold in other cancer categories than abdominal and in the nonoperative old and frail patients. This should be studied in future experimental studies.

Keywords: literature review, hemoglobin thresholds, guidelines, acute anemia, chronic anemia, tailored intervention

\section{Introduction}

Red blood cell (RBC) transfusions have been a standard for treating anemia for $>100$ years. ${ }^{1}$ In the 1990 s, researchers began to explore the evidence behind this practice. In the last decade, many randomized controlled trials (RCTs) and meta-analyses were performed in order to economize on erythrocyte components without impairing the clinical outcome. Most often, a restrictive RBC transfusion policy was compared with a more liberal one in various settings. Evidence supports that restrictive hemoglobin $\mathrm{Hb}$ ) thresholds are generally applicable to all care environments and that liberal $\mathrm{Hb}$ thresholds are important for subgroups of patients with cardiovascular disease (CVD) and in perioperative patients, especially the older ones.

The risk and benefits of RBC transfusions are complex. It is possible that the most optimal $\mathrm{Hb}$ threshold varies depending on underlying medical disorders. In patients with acute coronary syndrome and in frail older patients, a higher $\mathrm{Hb}$ concentration may be lifesaving. Of course, an increased blood volume may also increase the risk of pulmonary edema. ${ }^{2}$ 
In Denmark, 47.8 units of blood are annually spent per 1,000 inhabitants. $^{3}$ It is considered a challenge to reduce this high number of transfusions. Clinical guidelines across the world recommend adhering to a restrictive transfusion policy even if a liberal policy in itself may not be harmful. The decision to transfuse RBCs should be based upon a comprehensive and patient-specific clinical assessment. This review aims to evaluate the evidence (RCTs and meta-analyses) that the current transfusion guidelines are based upon.

\section{Assessment of the literature}

The authors searched the databases PubMed/MEDLINE, Embase, The Cochrane Library, CINAHL, and Google Scholar and included RCTs and meta-analyses from January 1996 to April 2016 using the keywords "blood transfusion", "transfusion", "red blood cell”, "threshold", "strategy", "policy", "liberal", and "restrictive". The RCTs and metaanalyses were grouped according to settings, diseases, countries, age groups, and outcomes. Meta-analyses that contained observational studies were excluded due to the risk of uncontrolled confounding as the need for RBC transfusion is a marker of illness burden. The reference lists of selected articles were also searched and screened ClinicalTrials.gov (the registry and results database of publicly and privately supported clinical studies of human participants conducted around the world) to identify relevant ongoing studies. Only full-text articles in the English language were reviewed.

The search identified 30 RCTs (Table 1) plus eight systematic reviews and meta-analyses solely based on RCTs comparing a restrictive $\mathrm{RBC}$ transfusion strategy with a more liberal RBC strategy (Table 2).

\section{Relevant clinical outcomes}

Most transfusion-related complications are rare and several of the RCTs are not powered to recognize the uncommon adverse events. The mostly used outcomes are mortality, cardiac morbidity (acute coronary syndrome), infections, functional recovery (lower extremity activities and activities of daily living [ADL]), length of hospital stay (LOS), quality of life (QoL), and further risk of bleeding. In some studies, intraoperative tissue oxygenation was used to measure the effect of the blood transfusions.

Mortality, cardiac events, and infection outcomes are typically used as markers of short-term outcomes 30 and 90 days after the acute event. Long-term functional outcomes are important and often not addressed when discussing RBC transfusion policy. Only one trial has measured 1-year mortality, ${ }^{4}$ another 1 -year physical recovery, ${ }^{5}$ and a third 3-year mortality. ${ }^{6}$ Primary and secondary outcomes vary depending on the hospital setting. Not all outcomes after hospital discharge are measured by face-to-face observations but by phone calls. Some patients are lost to follow-up due to loss of contact. The meta-analyses are challenged by various periods of follow-up and the different $\mathrm{Hb}$ thresholds used in the RCTs.

Seven of the RCTs are pilot studies ${ }^{7-13}$ and another seven base their results on $<200$ patients per trial ${ }^{14-20}$ and are probably too underpowered to explore differences in patient outcomes. Accordingly, they should be interpreted with caution. In the meta-analyses, the data from underpowered studies are useful. Eight systematic reviews and meta-analyses have been conducted within the last 5 years with the purpose to strengthen the estimates of the RCTs. ${ }^{21-28}$

\section{Hip and knee replacement}

Four RCTs have examined RBC transfusion policies in elective surgery. ${ }^{15,19,29,30}$ Implementation of transfusion protocols was accomplished during periods from 48 hours to 11 days. The mean age of the participants was from 69 to 71 years. Mortality and mobility were the primary outcome measures in these trials. Few of the patients died ( $0 \%-0.6 \%$ died within 30 days). The results did not permit any conclusion on short-term mortality. In 66 patients undergoing elective hip revision surgery, Nielsen et al ${ }^{19}$ found that a liberal RBC transfusion policy was associated with improved mobility (balance, walking speed, and mobility). However, the $\mathrm{Hb}$ did not differ within the groups and an association between better mobility and a higher $\mathrm{Hb}$ is highly questionable. ${ }^{19}$

\section{Hip fracture surgery}

Patients undergoing surgery for hip fracture are an ideal population to compare different transfusion policies. The patients constitute a large proportion of orthopedic patients. They are typically older, have coexisting diseases, and a high prevalence of preexisting anemia. Furthermore, fracture- and surgery-associated bleeding causes a high incidence of acute anemia and subsequent need for RBC transfusion rates, as well as relatively high mortality. The largest study until now is the multicenter FOCUS study. ${ }^{31}$ It included 2,016 participants at increased cardiovascular risk who were able to walk independently before the fracture occurred. A more liberal transfusion strategy was implemented within 3 days after surgery, but it did not improve the ability to walk independently or reduce mortality 60 days after surgery. Some of the patients in the restrictive group diverged from protocol. They were permitted 
Table I Randomized controlled trials published as articles in English language (January 1996-April 2016) in chronological order

\begin{tabular}{|c|c|c|c|c|c|c|c|c|}
\hline $\begin{array}{l}\text { First author, } \\
\text { country }\end{array}$ & Year & Journal & $\begin{array}{l}\text { Clinical setting/name of } \\
\text { study (if any) }\end{array}$ & $\begin{array}{l}\text { Number of } \\
\text { patients }\end{array}$ & $\begin{array}{l}\text { Mean } \\
\text { age, } \\
\text { years }\end{array}$ & $\begin{array}{l}\text { Hemoglobin } \\
\text { transfusion } \\
\text { thresholds } \\
\text { (restrictive vs } \\
\text { liberal), g/dL }\end{array}$ & Follow-up & Outcomes \\
\hline $\begin{array}{l}\text { Bush, }{ }^{14} \text { California, } \\
\text { USA }\end{array}$ & 1997 & Am J Surg & $\begin{array}{l}\text { Elective major arterial } \\
\text { reconstructions }\end{array}$ & 99 & 65 & 9 vs 10 & 30 days & Mortality \\
\hline $\begin{array}{l}\text { Carson, }{ }^{7} \mathrm{New} \\
\text { Jersey, USA }\end{array}$ & 1998 & Transfusion & Hip fracture surgery & 84 & 82 & 8 vs 10 & $\begin{array}{l}30 \text { days } \\
60 \text { days }\end{array}$ & $\begin{array}{l}\text { Mortality } \\
\text { Walking ability } \\
\text { Pneumonia }\end{array}$ \\
\hline $\begin{array}{l}\text { Bracey, }{ }^{43} \text { Texas, } \\
\text { USA }\end{array}$ & 1999 & Transfusion & $\begin{array}{l}\text { Primary coronary bypass } \\
\text { graft surgery }\end{array}$ & 428 & 61 & 8 vs 9 & In-hospital & $\begin{array}{l}\text { Mortality } \\
\text { Infections }\end{array}$ \\
\hline Hebert, ${ }^{35}$ Canada & 1999 & N Engl J Med & $\begin{array}{l}\text { ICU, critically ill patients } \\
\text { TRICC study }\end{array}$ & 838 & 58 & 7 vs 10 & $\begin{array}{l}\text { In-hospital } \\
30 \text { days } \\
60 \text { days }\end{array}$ & $\begin{array}{l}\text { Mortality* } \\
\text { Pneumonia }\end{array}$ \\
\hline $\begin{array}{l}\text { Lotke, }{ }^{15} \\
\text { Pennsylvania, USA }\end{array}$ & 1999 & J Arthroplasty & $\begin{array}{l}\text { Elective total knee } \\
\text { arthroplasty }\end{array}$ & 152 & 69 & $\begin{array}{l}9 \mathrm{~g} / \mathrm{dL} \text { vs } 2 \text { units of } \\
\text { autologous blood }\end{array}$ & 30 days & Mortality \\
\hline Hebert, ${ }^{36}$ Canada & 2001 & Crit Care Med & Critically ill with CVD & 357 & 65 & 7 vs 10 & $\begin{array}{l}\text { In-hospital } \\
30 \text { days } \\
60 \text { days }\end{array}$ & $\begin{array}{l}\text { Mortality } \\
\text { LOS }\end{array}$ \\
\hline Grover, ${ }^{29}$ UK & 2006 & Vox Sang & $\begin{array}{l}\text { Elective hip and knee } \\
\text { replacement }\end{array}$ & 218 & 71 & 8 vs 10 & 14 days & $\begin{array}{l}\text { Mortality } \\
\text { LOS } \\
\text { Adverse events }\end{array}$ \\
\hline Lacroix, ${ }^{37}$ Canada & 2007 & N Engl J Med & $\begin{array}{l}\text { Pediatric ICU, critically ill } \\
\text { children TRIPICU study }\end{array}$ & 637 & 3 & 7 vs 9.5 & 28 days & $\begin{array}{l}\text { Mortality } \\
\text { MODS }\end{array}$ \\
\hline Webert, ${ }^{8}$ Canada & 2008 & Transfusion & $\begin{array}{l}\text { Chemotherapy in acute } \\
\text { leukemia or stem cell } \\
\text { transplantation }\end{array}$ & 60 & 48 & 8 vs 12 & In-hospital & Bleeding risk \\
\hline Foss, ${ }^{16}$ Denmark & 2009 & Transfusion & Hip fracture surgery & 120 & 81 & 8 vs 10 & $\begin{array}{l}\text { In-hospital } \\
30 \text { days }\end{array}$ & $\begin{array}{l}\text { Mortality** } \\
\text { Ambulation } \\
\text { Infections } \\
\text { LOS }\end{array}$ \\
\hline Zygun, ${ }^{9}$ Canada & 2009 & Crit Care Med & Severe brain injury & 30 & 39 & 8 vs 9 vs 10 & $\begin{array}{l}30- \\
180 \text { minutes }\end{array}$ & Brain tissue oxygen \\
\hline $\begin{array}{l}\text { So-Osman, }{ }^{30} \\
\text { Holland }\end{array}$ & 2010 & Vos Sang & Elective orthopedic surgery & 603 & 70 & $\begin{array}{l}(7.2-9.7) \text { vs } \\
(9.7-10.5)\end{array}$ & 14 days & $\begin{array}{l}\text { Mortality } \\
\text { Infections }\end{array}$ \\
\hline Hajjar, ${ }^{44}$ Brazil & 2010 & JAMA & $\begin{array}{l}\text { Cardiopulmonary bypass } \\
\text { surgery TRACS-study }\end{array}$ & 512 & 59 & 9.2 vs 10.6 & 30 days & $\begin{array}{l}\text { Mortality } \\
\text { Severe morbidity }\end{array}$ \\
\hline $\begin{array}{l}\text { Cholette, }{ }^{17} \\
\text { New York, USA }\end{array}$ & 2011 & $\begin{array}{l}\text { Pediatr Crit } \\
\text { Care Med }\end{array}$ & $\begin{array}{l}\text { Single-ventricle physiology } \\
\text { post cavopulmonary } \\
\text { connection }\end{array}$ & 60 & 2.5 & 9 vs 13 & 48 hours & Arterial lactate leve \\
\hline $\begin{array}{l}\text { Cooper, }{ }^{10} \\
\text { Washington DC, } \\
\text { USA }\end{array}$ & 2011 & Am J Cardiol & Acute myocardial infarct & 45 & 73 & 8 vs 10.6 & $\begin{array}{l}\text { In-hospital } \\
30 \text { days }\end{array}$ & $\begin{array}{l}\text { Clinical event* } \\
\text { (death, AMI or new } \\
\text { or worsened heart } \\
\text { failure) }\end{array}$ \\
\hline $\begin{array}{l}\text { Carson, }{ }^{6,31} \text { USA, } \\
\text { Canada }\end{array}$ & 2011 & $\begin{array}{l}\text { N Engl J Med } \\
\text { and Lancet }\end{array}$ & $\begin{array}{l}\text { Hip fracture patients with } \\
\text { CVD } \\
\text { FOCUS study }\end{array}$ & 2,016 & 82 & 8 vs 10 & $\begin{array}{l}30 \text { days } \\
60 \text { days } \\
3 \text { years }\end{array}$ & $\begin{array}{l}\text { Mortality } \\
\text { Walking ability } \\
\text { Infections }\end{array}$ \\
\hline Shehata," Canada & 2012 & Transfusion & Cardiac surgery & 50 & 68 & 7.5 vs 10 & In-hospital & $\begin{array}{l}\text { Mortality } \\
\text { Infections } \\
\text { LOS }\end{array}$ \\
\hline $\begin{array}{l}\text { Nielsen, }{ }^{18} \\
\text { Denmark }\end{array}$ & 2012 & Transfus Med & Major spinal surgery & 48 & 61 & 7.3 vs 8.9 & $\begin{array}{l}60- \\
360 \text { minutes }\end{array}$ & $\begin{array}{l}\text { Subcutaneous } \\
\text { oxygen tension }\end{array}$ \\
\hline Villanueva, ${ }^{39}$ Spain & 2013 & N Engl J Med & $\begin{array}{l}\text { Acute upper } \\
\text { gastrointestinal bleeding }\end{array}$ & 921 & 65 & 7 vs 9 & 45 days & $\begin{array}{l}\text { Mortality* } \\
\text { Infections } \\
\text { Further bleeding* }\end{array}$ \\
\hline Walsh, ${ }^{12}$ UK & 2013 & Crit Care Med & $\begin{array}{l}\text { ICU - critically ill } \\
\text { mechanically ventilated }\end{array}$ & 100 & 67 & 7 vs 9 & $\begin{array}{l}30 \text { days } \\
60 \text { days } \\
180 \text { days }\end{array}$ & $\begin{array}{l}\text { Mortality } \\
\text { Antibiotic and } \\
\text { ventilation-free days }\end{array}$ \\
\hline
\end{tabular}


Table I (Continued)

\begin{tabular}{|c|c|c|c|c|c|c|c|c|}
\hline $\begin{array}{l}\text { First author, } \\
\text { country }\end{array}$ & Year & Journal & $\begin{array}{l}\text { Clinical setting/name of } \\
\text { study (if any) }\end{array}$ & $\begin{array}{l}\text { Number of } \\
\text { patients }\end{array}$ & $\begin{array}{l}\text { Mean } \\
\text { age, } \\
\text { years }\end{array}$ & $\begin{array}{l}\text { Hemoglobin } \\
\text { transfusion } \\
\text { thresholds } \\
\text { (restrictive vs } \\
\text { liberal), g/dL }\end{array}$ & Follow-up & Outcomes \\
\hline $\begin{array}{l}\text { Carson, }{ }^{13} \mathrm{New} \\
\text { Jersey, USA }\end{array}$ & 2013 & Am Heart J & $\begin{array}{l}\text { Acute coronary syndrome } \\
\text { or stable angina undergoing } \\
\text { cardiac catheterization }\end{array}$ & 110 & 71 & 8 vs 10 & $\begin{array}{l}30 \text { days } \\
6 \text { months }\end{array}$ & $\begin{array}{l}\text { Mortality** } \\
\text { Cardiac events }\end{array}$ \\
\hline Parker, ${ }^{4}$ UK & 2013 & Injury & Hip fracture surgery & 200 & 84 & $\begin{array}{l}\text { Symptoms of } \\
\text { anemia vs } 10 \mathrm{~g} / \mathrm{dL} \\
\text { ( } 2 \text { units) }\end{array}$ & $\begin{array}{l}30 \text { days } \\
90 \text { days } \\
120 \text { days } \\
\text { I year }\end{array}$ & $\begin{array}{l}\text { Mortality } \\
\text { Physical ability }\end{array}$ \\
\hline Prick, ${ }^{42}$ Holland & 2014 & BJOG & $\begin{array}{l}\text { Severe postpartum } \\
\text { hemorrhage }\end{array}$ & 521 & 31 & No RBC vs 8.9 & $\begin{array}{l}3 \text { days } \\
\text { I week } \\
3 \text { weeks } \\
6 \text { weeks }\end{array}$ & $\begin{array}{l}\text { Fatigue* } \\
\text { QoL }\end{array}$ \\
\hline $\begin{array}{l}\text { Robertson, }{ }^{34} \\
\text { Texas, USA }\end{array}$ & 2014 & JAMA & Traumatic brain injury & 200 & 30 & 7 vs 10 & 6 months & $\begin{array}{l}\text { Mortality } \\
\text { Infections } \\
\text { ARDS } \\
\text { Thromboembolic } \\
\text { events* }\end{array}$ \\
\hline $\begin{array}{l}\text { Nielsen, }{ }^{19} \\
\text { Denmark }\end{array}$ & 2014 & $\begin{array}{l}\text { BMC } \\
\text { Anesthesiol }\end{array}$ & $\begin{array}{l}\text { Elective hip revision } \\
\text { surgery }\end{array}$ & 66 & 70 & 7.3 vs 8.9 & 30 days & Physical ability** \\
\hline $\begin{array}{l}\text { Holst, }{ }^{38} \text { Denmark, } \\
\text { Norway, Sweden, } \\
\text { Finland }\end{array}$ & 2014 & N Engl J Med & $\begin{array}{l}\text { Septic shock in the ICU } \\
\text { TRISS study }\end{array}$ & 998 & 67 & 7 vs 9 & 90 days & $\begin{array}{l}\text { Mortality } \\
\text { Ischemic events } \\
\text { Serious adverse } \\
\text { event }\end{array}$ \\
\hline $\begin{array}{l}\text { de Almeida, }{ }^{20} \\
\text { Brazil }\end{array}$ & 2015 & Anesthesiology & $\begin{array}{l}\text { Surgery for abdominal } \\
\text { cancer }\end{array}$ & 198 & 64 & 7 vs 9 & $\begin{array}{l}30 \text { days } \\
60 \text { days }\end{array}$ & $\begin{array}{l}\text { Mortality** } \\
\text { Infections** }\end{array}$ \\
\hline $\begin{array}{l}\text { Gregersen, } \\
\text { Denmark }\end{array}$ & 2015 & $\begin{array}{l}\text { Acta Orthop } \\
\text { and J Am Med } \\
\text { Dir Assoc }\end{array}$ & $\begin{array}{l}\text { Hip facture surgery } \\
\text { TRIFE study }\end{array}$ & 284 & 86 & 9.7 vs 11.3 & $\begin{array}{l}30 \text { days } \\
90 \text { days } \\
\text { I year }\end{array}$ & $\begin{array}{l}\text { Physical ability** } \\
\text { Mortality } \\
\text { QoL }\end{array}$ \\
\hline Jairath, ${ }^{41}$ UK & 2015 & Lancet & $\begin{array}{l}\text { Acute upper } \\
\text { gastrointestinal bleeding } \\
\text { TRIGGER study }\end{array}$ & 936 & 59 & 8 vs 10 & $\begin{array}{l}\text { In-hospital } \\
28 \text { days }\end{array}$ & $\begin{array}{l}\text { Bleeding } \\
\text { Infections } \\
\text { Mortality } \\
\text { Adverse event } \\
\text { QoL }\end{array}$ \\
\hline Murphy, ${ }^{45}$ UK & 2015 & N Engl J Med & Cardiac surgery & 2,003 & 70 & 7.5 vs 9 & 90 days & $\begin{array}{l}\text { Serious infections } \\
\text { Ischemic events } \\
\text { Mortality** } \\
\text { Health costs }\end{array}$ \\
\hline
\end{tabular}

Notes: *Statistical significant difference in favor of the restrictive strategy. **Statistical significant difference in favor of the liberal strategy.

Abbreviations: ICU, intensive care unit; MODS, multiple-organ-dysfunction syndrome; LOS, length of hospital stay; QoL, quality of life; ARDS, adult respiratory distress syndrome; CVD, cardiovascular disease; RBC, red blood cell.

to receive $\mathrm{RBC}$ transfusion if signs of anemia were present due to chest pain, congestive heart failure, unexpected tachycardia, hypotension unresponsive to fluid replacement, or in patients with clinically diagnosed dementia because they might not be able to report their symptoms. These patients may have been the frailest with the highest risk of death neutralizing a possible difference. This was also the case in the study of hip fracture patients by Parker. ${ }^{4}$ They found no difference in the outcomes related to transfusion. ${ }^{4}$

In Denmark, two RCTs have been conducted in hip fracture patients. Foss et a ${ }^{16}$ recruited nonfrail older patients and concluded that a restrictive threshold policy should be used with caution. Neither did Gregersen et $\mathrm{al}^{32}$ find any differences in the clinical outcomes (TRIFE study). However, in a subgroup analysis of the outcome for nursing home residents (mean age 87 years) a liberal strategy demonstrated an improved survival within 90 days after surgery. ${ }^{32}$ The liberal strategy also reduced the number of patients in a state of delirium 10 days after hip fracture repair, ${ }^{33} 25 \%$ of the participants died within a year. In the survivors, ADL recovery was improved in the liberal transfusion group. ${ }^{5}$ In a Cochrane review, Brunskill et $\mathrm{al}^{25}$ included 2,722 hip 
Table 2 Systematic reviews and meta-analyses published in English language (January 1996-April 2016) in chronological order

\begin{tabular}{|c|c|c|c|c|c|c|c|c|}
\hline $\begin{array}{l}\text { First author, } \\
\text { country }\end{array}$ & Year & Journal & Clinical setting & $\begin{array}{l}\text { Number } \\
\text { of patients }\end{array}$ & $\begin{array}{l}\text { Number } \\
\text { of RCTs }\end{array}$ & $\begin{array}{l}\text { Restrictive Hb } \\
\text { thresholds, } \\
\text { g/dL }\end{array}$ & $\begin{array}{l}\text { Liberal Hb } \\
\text { thresholds, } \\
\text { g/dL }\end{array}$ & Outcomes \\
\hline $\begin{array}{l}\text { Carson, }{ }^{21} \\
\text { New Jersey, } \\
\text { USA }\end{array}$ & 2012 & $\begin{array}{l}\text { Cochrane } \\
\text { Database } \\
\text { Syst Rev }\end{array}$ & $\begin{array}{l}\text { Critical illness, } \\
\text { trauma, and surgery }\end{array}$ & 6,264 & 19 & $7-9$ & $9-10$ & $\begin{array}{l}\text { In hospital } \\
\text { mortality* } \\
30 \text { - and 60-day } \\
\text { mortality } \\
\text { Physical ability } \\
\text { Adverse events }\end{array}$ \\
\hline $\begin{array}{l}\text { Wang, }{ }^{22} \text { The } \\
\text { People's } \\
\text { Republic of } \\
\text { China }\end{array}$ & 2013 & $\begin{array}{l}\text { World J } \\
\text { Gastroenterol }\end{array}$ & $\begin{array}{l}\text { Gastrointestinal } \\
\text { bleeding }\end{array}$ & 982 & 4 & $\begin{array}{l}7-8, \text { plasma } \\
\text { protein, or } \\
\text { hematocrit } 21 \%\end{array}$ & $\begin{array}{l}9, \geq 2 \\
\text { units, or } \\
\text { hematocrit } \\
28 \%\end{array}$ & $\begin{array}{l}\text { Mortality* } \\
\text { LOS* } \\
\text { Rebleeding }\end{array}$ \\
\hline $\begin{array}{l}\text { Salpeter, }{ }^{23} \\
\text { New York, } \\
\text { USA }\end{array}$ & 2014 & Am J Med & $\begin{array}{l}\text { Critical illness and } \\
\text { gastrointestinal } \\
\text { bleeding }\end{array}$ & 2,364 & 3 & 7 & $9-10$ & $\begin{array}{l}\text { Cardiac } \\
\text { events* } \\
\text { Rebleeding* } \\
\text { Mortality* } \\
\text { Infections }\end{array}$ \\
\hline $\begin{array}{l}\text { Rohde, }^{24} \\
\text { Michigan, USA }\end{array}$ & 2014 & JAMA & $\begin{array}{l}\text { Critical illness, } \\
\text { trauma, and surgery }\end{array}$ & 7,593 & 18 & $6.4-9.7$ & $9-11.3$ & $\begin{array}{l}\text { Healthcare- } \\
\text { associated } \\
\text { infections } \\
\text { Serious } \\
\text { infections* }\end{array}$ \\
\hline $\begin{array}{l}\text { Holst, }{ }^{27} \\
\text { Denmark }\end{array}$ & 2015 & BMJ & $\begin{array}{l}\text { Critical illness, } \\
\text { trauma, and surgery }\end{array}$ & 9,813 & 31 & $7-9$ & $9-10$ & $\begin{array}{l}\text { Mortality } \\
\text { Myocardial } \\
\text { infarction } \\
\text { Infections* }\end{array}$ \\
\hline Brunskill, ${ }^{25}$ UK & 2015 & $\begin{array}{l}\text { Cochrane } \\
\text { Database } \\
\text { Syst Rev }\end{array}$ & Hip fracture surgery & 2,722 & 6 & $7-9.7$ & $8.9-11.3$ & $\begin{array}{l}\text { Mortality } \\
\text { Functional } \\
\text { recovery } \\
\text { Morbidity }\end{array}$ \\
\hline $\begin{array}{l}\text { Fominskiy, }{ }^{26} \\
\text { Italy }\end{array}$ & 2015 & Br J Anaesth & $\begin{array}{l}\text { Perioperative setting } \\
\text { Critically ill }\end{array}$ & $\begin{array}{l}7,552 \\
3,469\end{array}$ & $\begin{array}{l}17 \\
10\end{array}$ & $\begin{array}{l}7-9.7 \\
7-9\end{array}$ & $\begin{array}{l}8.9-11.3 \\
9-10\end{array}$ & $\begin{array}{l}\text { All-cause } \\
\text { mortality** } \\
\text { All-cause } \\
\text { mortality }\end{array}$ \\
\hline $\begin{array}{l}\text { Docherty, }{ }^{28} \\
\text { UK }\end{array}$ & 2016 & $B M J$ & $\begin{array}{l}\text { Cardiovascular } \\
\text { disease in } \\
\text { orthopedics, } \\
\text { gastrointestinal } \\
\text { bleeding, critical } \\
\text { care, and cardiac } \\
\text { surgery }\end{array}$ & 3,033 & 11 & $7-9.7$ & $9-11.3$ & $\begin{array}{l}\text { Mortality } \\
\text { Acute } \\
\text { coronary } \\
\text { syndrome** }\end{array}$ \\
\hline
\end{tabular}

Notes: *Statistical significant difference in favor of the restrictive strategy. **Statistical significant difference in favor of the liberal strategy. Abbreviations: RCTs, randomized controlled trials; LOS, length of hospital stay; Hb, hemoglobin.

fracture patients (6 RTCs). Mortality, physical recovery, and morbidity were not associated with the transfusion policies. The authors pointed out that future research would need to focus on patients who have symptoms of impaired blood flow. Such patients were excluded from most trials..$^{25}$

\section{Abdominal cancer}

In 198 patients subjected to major gastrointestinal cancer surgery, de Almeida et $\mathrm{al}^{20}$ found that a liberal transfusion strategy provides better outcomes than a restrictive as low as $7 \mathrm{~g} / \mathrm{dL}$. Survival within 30 and 60 days was improved and the patients had less abdominal infections. ${ }^{20}$ The number of cardiovascular complications was also lower in the liberal group (5.2\% vs $13.9 \%$ ). The mean age of the patients was 64 years. Both elective and emergency surgical patients were included. The authors consider that cancer patients receiving restrictive transfusion may be more susceptible to altered oxygen delivery in the postoperative period due to impaired microvascular flow. No other trials are completed in only the oncologic patients. 


\section{Traumatic brain injury and spinal surgery}

Patients with severe traumatic brain injury commonly develop anemia. RBC transfusions result in improved brain tissue oxygen without appreciable effect on cerebral metabolism. ${ }^{9}$ This transfusion practice was expected to reduce the neurological injuries. However, in an RCT from 2014, a liberal transfusion threshold of $10 \mathrm{~g} / \mathrm{dL}$ was associated with a higher incidence of thromboembolic events in 200 patients with traumatic brain injury. ${ }^{34}$ Nielsen et $\mathrm{a}^{18}$ found that during major spinal surgery a higher threshold was not associated with a higher subcutaneous oxygen tension.

\section{Critically ill patients}

In patients admitted to an intensive care unit (eg, TRICC study, TRIPICU study, and TRISS study), a restrictive strategy is at least as effective as a liberal. ${ }^{12,35-37}$ In the TRICC study, the critically ill patient had a mean age of 58 years. The mortality rate during hospitalization was lower in the restrictive transfusion group..$^{35} \mathrm{~A}$ restrictive $\mathrm{RBC}$ transfusion strategy generally appears to be safe in critically ill patients with CVDs, though there may be an exception in patients with severe ischemic heart disease. ${ }^{36}$ In the TRIPICU study, the population was children with a mean age of 3 years and a mean intervention period of 2.3 days. Nor in that study a significant difference was found in mortality rates or infectious complication rates. ${ }^{37} \mathrm{~A}$ multicenter study from the Scandinavian countries (TRISS study), in which 998 patients were enrolled, the restrictive transfusion policy did not harm the septic shock patients. The number of days alive, ischemic events, and severe adverse reactions to blood were similar in the two groups. In the TRISS study, all participants who fulfilled the inclusion criteria had septic shock before the randomization. ${ }^{38}$ In a pilot study of 100 critically ill patients hospitalized in an intensive care unit, Walsh et al ${ }^{12}$ found a nonsignificant trend toward a lower 180-day mortality rate connected with a restrictive policy.

\section{Upper gastrointestinal bleeding}

A restrictive strategy reduced the 45-day mortality rate in 921 cases of acute upper gastrointestinal bleeding in patients aged 18 years or older. ${ }^{39}$ Deaths due to initial unsuccessfully controlled bleeding were not equally distributed between the transfusion groups: three patients $(0.7 \%)$ died in the restrictive strategy group vs 14 patients $(3.1 \%)$ in the liberal strategy group $(P=0.01)$. Simply by equalizing the patient number in this category, death and transfusion policy were no longer related. ${ }^{40}$ The ongoing bleeding may have contributed to the increased mortality. Jairath et $\mathrm{al}^{41}$ examined $\mathrm{RBC}$ transfusion strategies in 936 patients in the TRIGGER study. They found no difference in clinical outcomes. ${ }^{41}$ In a meta-analysis concerning only patients with upper gastrointestinal bleeding (4 RCTs), the mortality was lower in patients treated according to a restrictive transfusion strategy. Also, the patients had a shorter LOS in the restrictive group based on two of the four trials. ${ }^{22}$ Three of the trials weighted only for $9.5 \%$ of the result, whereas the RCT of Villanueva et al ${ }^{39}$ weighted for the most. However, in older people with acute upper gastrointestinal bleeding, it is not clear if a restrictive approach to transfusion is safe.

\section{Severe postpartum hemorrhage}

In a multicenter study in 521 women with sustained postpartum hemorrhage, an $\mathrm{Hb}$ threshold of $8.9 \mathrm{~g} / \mathrm{dL}$ was compared with no transfusion or transfusion only if severe symptom of anemia appeared within 12 hours after delivery. The authors recorded physical fatigue and found that women randomized to nonintervention showed a higher mean fatigue score. The clinical relevance of this difference seemed negligible. ${ }^{42}$

\section{Cardiopulmonary surgery}

A lower threshold does not adversely affect patient outcome in cardiac surgery. ${ }^{11,14,43,44}$ However, Murphy et a ${ }^{45}$ conducted a multicenter RCT in 17 cardiac surgery centers in the UK. It included 2,003 participants. Three months after randomization more deaths were found in the restrictive threshold group than in the liberal group ( $4.2 \%$ vs $2.6 \%)$. There was no difference with regard to serious infections, ischemic events, or QoL. ${ }^{45}$ Carson et $a{ }^{13}$ found that in patients with acute coronary syndrome or stable angina undergoing cardiac catheterization subjected to the restrictive strategy had more than twice the rate of death, myocardial infarction, or revascularization in the first 30 days of care compared to patients following a more liberal strategy. In the TRACS study of 512 adults undergoing cardiopulmonary bypass surgery, there was no difference in mortality and infection risk with regard to the RBC transfusion policy. ${ }^{44}$ However, in patients aged 60 years or older, cardiogenic shock was more frequent in the restrictive transfusion group. In the patients $<60$ years no such difference was found. ${ }^{46}$ In infants and children with elective partial or total cavopulmonary connection, Cholette et $\mathrm{al}^{17}$ found no benefit from a liberal transfusion strategy with an $\mathrm{Hb}$ threshold of $13 \mathrm{~g} / \mathrm{dL}$ compared to a restrictive of $9 \mathrm{~g} / \mathrm{dL}$ within 48 hours after surgery. 


\section{CVD}

A recent meta-analysis suggested that for 3,033 patients with CVD (11 RCTs), the restrictive transfusion thresholds were associated with higher rates of acute coronary syndrome than the more liberal transfusion thresholds. The authors found a tendency toward lower 30-day mortality with a liberal policy. The authors concluded that a high-quality RCT has to be undertaken in CVD patients due to the diversity between trial populations and the varied thresholds between trials. ${ }^{28}$

\section{Various disease groups}

In a Cochrane review from 2012 including 6,264 patients with various diseases and settings (19 RCTs), Carson et $\mathrm{al}^{21}$ showed higher in-hospital mortality in patients receiving liberal transfusions compared to those following a restrictive strategy. No difference was found in 30- or 60-day mortality and neither in infections nor in physical abilities. ${ }^{21}$ Holst et $\mathrm{al}^{27}$ carried out a similar study and added the RCT data published in the last 3 years to examine whether the evidence of the previous meta-analyses still supported a restrictive strategy without harming the patient. The analysis now including 9,813 patients (31 RCTs) confirmed the findings of Carson et al. ${ }^{21}$

Rohde et a ${ }^{24}$ found that serious infections were related to a liberal policy in pooled data from 7,593 patients (18 RCTs). However, health care-associated infections such as pneumonia, mediastinitis, wound infection, and sepsis were not linked to a liberal strategy. The definitions of serious infections and health care-associated infections were not clear when comparing data from the included studies. ${ }^{24}$

In 7,552 perioperative patients (17 RCTs), Fominskiy et $\mathrm{al}^{26}$ found that a liberal blood transfusion strategy improved survival in acute anemia. The perioperative settings were hip fracture surgery, cardiac surgery, abdominal cancer surgery, elective hip and knee replacement, spinal fusion with instrumentation, and postpartum hemorrhage. In 2014, Salpeter et $\mathrm{al}^{23}$ studied 2,364 patients ( $3 \mathrm{RCTs}$ ) and pooled the results from patients with critical illness with the results from the bleeding patients and found that a restrictive strategy $(\mathrm{Hb}$ threshold $7 \mathrm{~g} / \mathrm{dL}$ ) reduced cardiac events, rebleeding, and 30-day mortality. No difference in infection risk was found in the disparate populations. ${ }^{23}$ The motives for combining medical patients, gastrointestinal bleeding patients, and adults and children in the meta-analysis are not clear.

\section{RBC transfusion thresholds}

Most trials have used a "restrictive" $\mathrm{Hb}$ threshold of 7 or $8 \mathrm{~g}$ / $\mathrm{dL}$, a few trials between 9.0 and $9.7 \mathrm{~g} / \mathrm{dL}$. The mostly used "liberal" Hb threshold was $10 \mathrm{~g} / \mathrm{dL}$ (Table 1). Four trials used a liberal $\mathrm{Hb}$ threshold of $9 \mathrm{~g} / \mathrm{dL}$ (similar to the restrictive threshold in other trials). One RCT used a threshold of $11.3 \mathrm{~g} / \mathrm{dL},{ }^{32}$ another $12 \mathrm{~g} / \mathrm{dL},{ }^{8}$ and a third $13 \mathrm{~g} / \mathrm{dL} .{ }^{17}$ A challenge of the trials was protocol adherence. In some studies, eg, FOCUS, TRICC, TRACS, and TRISS, the patients in the restrictive RBC transfusion group were transfused when $\mathrm{Hb}$ concentrations were higher than those of the protocol thresholds. Likewise, there was a lower adherence to the liberal policy. This may have been due to the clinicians' knowledge of the present guidelines advocating a restrictive transfusion policy. Per-protocol analyses are unfortunately rarely presented in the trials.

Some studies used leukocyte-reduced blood, others nonreduced. Also, the varying lengths of protocol implementation, an insignificant interval between the $\mathrm{Hb}$ thresholds in the two transfusion groups, different liberal and restrictive thresholds across the trials, and various disease and age groups must all influence the general evidence of the meta-analyses.

\section{Should age influence transfusion strategies?}

A patient's ability to tolerate anemia depends on how quickly compensatory mechanisms develop. ${ }^{47}$ In the pediatric age group, two trials have been conducted in children with singleventricle physiology postcavopulmonary connection and in critically ill children. No outcome improvements were found by a higher $\mathrm{Hb}$ concentration. ${ }^{17,37}$ However, in older age the compensatory functions are reduced. Several studies have demonstrated the association between chronic anemia and mortality in critical illness. ${ }^{48}$ Low $\mathrm{Hb}$ concentrations represent underlying diseases and are related to the severity of the disease, immune function, and comorbidity. Old age is highly correlated with lower immune function, less physiologic reserves as well as more severe cardiac diseases. Frailty prevalence increases with age from $3.9 \%$ in the age $65-74$ years to $25 \%$ in the age group $>85$ years. ${ }^{49}$ Anemia in frail older persons is related to 90 -day mortality. ${ }^{50}$ Older hospitalized patients are at high risk to become delirious, and the risk of delirium is associated with advanced age and an $\mathrm{Hb}<10 \mathrm{~g} / \mathrm{dL} .{ }^{51}$ Acute anemia $(\mathrm{Hb}<10 \mathrm{~g} / \mathrm{dL})$ is associated with complications such as pneumonia and myocardial infarction. ${ }^{52}$ In patients who undergo surgery, the level of frailty is related to adverse outcomes such as postoperative complications, delayed recovery, morbidity, and mortality. ${ }^{53}$ Overall, anemia in older people has been well documented as being an independent risk factor for increased mortality, reduced physical performance, hospital readmissions, falls, and impaired cognition. ${ }^{54,55}$ It is reasonable 
to make the assumption that a liberal transfusion policy may be lifesaving in the frail and oldest patients.

Previous RCTs have been conducted in children or adults aged $16 / 18$ years or older. Only the TRACS study carried out analyses in young and old age groups separately. The outcomes after cardiopulmonary bypass surgery were improved by a liberal transfusion policy in patients aged 60 years or older. This difference was not present in younger patients. ${ }^{46}$ Only six of the 30 RCTs used age inclusion criteria $>18$ years: $\geq 50$ years in hip fracture patients, ${ }^{31} \geq 55$ years in critically ill patients and elective surgery, ${ }^{12,29} \geq 60$ years, ${ }^{4}$ and $\geq 65$ years in hip fracture patients, ${ }^{16,56}$ and $\geq 70$ years in elective hipand knee replacement patients (a high-risk subgroup).$^{30}$ For the FOCUS study, Carson et $\mathrm{al}^{31}$ selected high-risk patients defined by CVD. Only Gregersen et $\mathrm{al}^{32}$ examined the RBC transfusion policies in the frail older patients. The frail older patients, defined by a nursing home residency, with acute anemia did benefit from a more liberal transfusion policy.

\section{Conclusion}

Current studies still support that restrictive $\mathrm{Hb}$ thresholds are applicable to all care environments with the exception of important subgroups of patients with CVD and perioperative patients with acute anemia, who require a more liberal transfusion approach. The restrictive policy is adverse to the assumption that oxygen delivery to the vital organs is helpful to nonsurgical patients recovering from acute illness. In many countries, there is a need to reduce transfusion overuse. $A$ reduction in the number of $\mathrm{RBC}$ units and of patients transfused is possible when applying a restrictive policy. ${ }^{27}$

Guidelines for transfusion policy are important in the clinical settings. Even though the guidelines are based upon trials rated at the highest evidence level, they may not have been performed congruently. As seen in several of the trials, the thresholds diverged from the protocol due to signs of anemia. In the clinic (as in research), it is similarly crucial to have the opportunity to deviate from the guidelines if signs of anemia are present and to tailor the transfusion strategy to each patient.

\section{Future implications}

Trials on transfusion policies are still ongoing and may indicate that the guidelines have not yet convinced the clinicians and researchers that a restrictive policy is the right choice. This may be due to the limitations of the previous experimental studies, and the knowledge that anemia in the immediate postoperative period can impede early recovery and prolong hospital stay. ${ }^{57,58}$ According to "ClinicalTrials.gov", the settings in progress are acute myocardial infarction, cardiac surgery, aneurysmal subarachnoid hemorrhage, acute leukemia, and vascular surgery. All studies are conducted in adults aged 18 years or older. To the authors' knowledge, no ongoing studies on RBC transfusion thresholds are focusing on the older and frail patients. It is a normal procedure to perform trials in pediatric setting or in adults in different disease groups. However, the influence of old age and frailty status in a geriatric setting should be studied in future RCTs or meta-analyses with regard to RBC transfusion strategies.

\section{Disclosure}

The authors report no conflicts of interest in this work.

\section{References}

1. Baskett TF. James blundell: the first transfusion of human blood. Resuscitation. 2002;52(3):229-233.

2. Carson JL, Hebert PC. Should we universally adopt a restrictive approach to blood transfusion? it's all about the number. Am J Med. 2014;127(2):103-104.

3. Sundhedsstyrelsen [homepage on the Internet]. En national klinisk retningslinje om indikation for transfusion med blodkomponenter; 2014. Available from: http://sst.dk/. Accessed May 4, 2016.

4. Parker MJ. Randomised trial of blood transfusion versus a restrictive transfusion policy after hip fracture surgery. Injury. 2013;44(12):1916-1918.

5. Gregersen M, Borris LC, Damsgaard EM. Blood transfusion and overall quality of life after hip fracture in frail elderly patients -the transfusion requirements in frail elderly randomized controlled trial. JAm Med Dir Assoc. 2015;16(9):762-766.

6. Carson JL, Sieber F, Cook DR, et al. Liberal versus restrictive blood transfusion strategy: 3-year survival and cause of death results from the FOCUS randomised controlled trial. Lancet. 2015;385(9974):1183-1189.

7. Carson JL, Terrin ML, Barton FB, et al. A pilot randomized trial comparing symptomatic vs. hemoglobin-level-driven red blood cell transfusions following hip fracture. Transfusion. 1998;38(6):522-529.

8. Webert KE, Cook RJ, Couban S, et al. A multicenter pilot-randomized controlled trial of the feasibility of an augmented red blood cell transfusion strategy for patients treated with induction chemotherapy for acute leukemia or stem cell transplantation. Transfusion. 2008;48(1):81-91.

9. Zygun DA, Nortje J, Hutchinson PJ, Timofeev I, Menon DK, Gupta AK. The effect of red blood cell transfusion on cerebral oxygenation and metabolism after severe traumatic brain injury. Crit Care Med. 2009;37(3):1074-1078.

10. Cooper HA, Rao SV, Greenberg MD, et al. Conservative versus liberal red cell transfusion in acute myocardial infarction (the CRIT randomized pilot study). Am J Cardiol. 2011;108(8):1108-1111.

11. Shehata N, Burns LA, Nathan H, et al. A randomized controlled pilot study of adherence to transfusion strategies in cardiac surgery. Transfusion. 2012;52(1):91-99.

12. Walsh TS, Boyd JA, Watson D, et al. Restrictive versus liberal transfusion strategies for older mechanically ventilated critically ill patients: a randomized pilot trial. Crit Care Med. 2013;41(10):2354-2363.

13. Carson JL, Brooks MM, Abbott JD, et al. Liberal versus restrictive transfusion thresholds for patients with symptomatic coronary artery disease. Am Heart J. 2013;165(6):964;971.e1.

14. Bush RL, Pevec WC, Holcroft JW. A prospective, randomized trial limiting perioperative red blood cell transfusions in vascular patients. Am J Surg. 1997;174(2):143-148.

15. Lotke PA, Barth P, Garino JP, Cook ER. Predonated autologous blood transfusions after total knee arthroplasty: immediate versus delayed administration. J Arthroplasty. 1999;14(6):647-650. 
16. Foss NB, Kristensen MT, Jensen PS, Palm H, Krasheninnikoff M, Kehlet $\mathrm{H}$. The effect of liberal versus restrictive transfusion thresholds on ambulation after hip fracture surgery. Transfusion. 2009;49(2):227-234.

17. Cholette JM, Rubenstein JS, Alfieris GM, Powers KS, Eaton M, Lerner NB. Children with single-ventricle physiology do not benefit from higher hemoglobin levels post cavopulmonary connection: results of a prospective, randomized, controlled trial of a restrictive versus liberal red-cell transfusion strategy. Pediatr Crit Care Med. 2011;12(1):39-45.

18. Nielsen K, Dahl B, Johansson PI, Henneberg SW, Rasmussen LS. Intraoperative transfusion threshold and tissue oxygenation: a randomised trial. Transfus Med. 2012;22(6):418-425.

19. Nielsen K, Johansson PI, Dahl B, et al. Perioperative transfusion threshold and ambulation after hip revision surgery - a randomized trial. BMC Anesthesiol. 2014;14:89.

20. de Almeida JP, Vincent JL, Galas FR, et al. Transfusion requirements in surgical oncology patients: a prospective, randomized controlled trial. Anesthesiology. 2015;122(1):29-38.

21. Carson JL, Carless PA, Hebert PC. Transfusion thresholds and other strategies for guiding allogeneic red blood cell transfusion. Cochrane Database Syst Rev. 2012;4:CD002042.

22. Wang J, Bao YX, Bai M, Zhang YG, Xu WD, Qi XS. Restrictive vs liberal transfusion for upper gastrointestinal bleeding: a metaanalysis of randomized controlled trials. World $J$ Gastroenterol. 2013;19(40):6919-6927.

23. Salpeter SR, Buckley JS, Chatterjee S. Impact of more restrictive blood transfusion strategies on clinical outcomes: a meta-analysis and systematic review. Am J Med. 2014;127(2):124;131.e3.

24. Rohde JM, Dimcheff DE, Blumberg N, et al. Health care-associated infection after red blood cell transfusion: a systematic review and metaanalysis. JAMA. 2014;311(13):1317-1326.

25. Brunskill SJ, Millette SL, Shokoohi A, et al. Red blood cell transfusion for people undergoing hip fracture surgery. Cochrane Database Syst Rev. 2015;4:CD009699.

26. Fominskiy E, Putzu A, Monaco F, et al. Liberal transfusion strategy improves survival in perioperative but not in critically ill patients. A meta-analysis of randomised trials. Br JAnaesth. 2015;115(4):511-519.

27. Holst LB, Petersen MW, Haase N, Perner A, Wetterslev JØ. Restrictive versus liberal transfusion strategy for red blood cell transfusion: systematic review of randomised trials with meta-analysis and trial sequential analysis. BMJ. 2015;350:h1354.

28. Docherty AB, O’Donnell R, Brunskill S, et al. Effect of restrictive versus liberal transfusion strategies on outcomes in patients with cardiovascular disease in a non-cardiac surgery setting: systematic review and metaanalysis. BMJ. 2016;352(i1351).

29. Grover M, Talwalkar S, Casbard A, et al. Silent myocardial ischaemia and haemoglobin concentration: a randomized controlled trial of transfusion strategy in lower limb arthroplasty. Vox Sang. 2006;90(2):105-112.

30. So-Osman C, Nelissen R, Te Slaa R, Coene L, Brand R, Brand A. A randomized comparison of transfusion triggers in elective orthopaedic surgery using leucocyte-depleted red blood cells. Vox Sang. 2010;98(1):56-64.

31. Carson JL, Terrin ML, Noveck H, et al. Liberal or restrictive transfusion in high-risk patients after hip surgery. $N$ Engl $J$ Med. 2011;365(26):2453-2462.

32. Gregersen M, Borris L, Damsgaard EM. Postoperative blood transfusion strategy in frail anemic elderly with hip fracture: the TRIFE randomized controlled trial. Acta Orthop. 2015;86(3):363-372.

33. Blandfort S, Gregersen M, Borris LC. Damsgaard E.M. Blood transfusion strategy and risk of postoperative delirium in nursing homes residents with hip fracture. a post-hoc analysis based on the TRIFE randomized controlled trial. Aging Clin Exp Res. Epub 2016 Jun 1.

34. Robertson CS, Hannay HJ, Yamal JM, et al. Effect of erythropoietin and transfusion threshold on neurological recovery after traumatic brain injury: a randomized clinical trial. JAMA. 2014;312(1):36-47.

35. Hebert PC, Wells G, Blajchman MA, et al. A multicenter, randomized, controlled clinical trial of transfusion requirements in critical care. $N$ Engl J Med. 1999;340(6):409-417.
36. Hebert PC, Yetisir E, Martin C, et al. Is a low transfusion threshold safe in critically ill patients with cardiovascular diseases? Crit Care Med. 2001;29(2):227-234.

37. Lacroix J, Hebert PC, Hutchison JS, et al. Transfusion strategies for patients in pediatric intensive care units. $N$ Engl $J$ Med. 2007;356(16):1609-1619.

38. Holst LB, Haase N, Wetterslev J, et al. Lower versus higher hemoglobin threshold for transfusion in septic shock. $N$ Engl $J$ Med. 2014;371(15):1381-1391

39. Villanueva $\mathrm{C}$, Colomo A, Bosch A, et al. Transfusion strategies for acute upper gastrointestinal bleeding. N Engl J Med. 2013;368(1):11-21.

40. Mirski MA, Frank SM, Kor DJ, Vincent JL, Holmes DR Jr. Restrictive and liberal red cell transfusion strategies in adult patients: reconciling clinical data with best practice. Crit Care. 2015;19:202.

41. Jairath V, Kahan BC, Gray A, et al. Restrictive versus liberal blood transfusion for acute upper gastrointestinal bleeding (TRIGGER): a pragmatic, open-label, cluster randomised feasibility trial. Lancet. 2015;386(9989):137-144

42. Prick BW, Jansen AJG, Steegers EAP, et al. Transfusion policy after severe postpartum haemorrhage: a randomised non-inferiority trial. BJOG. 2014;121(8):1005-1014.

43. Bracey AW, Radovancevic R, Riggs SA, et al. Lowering the hemoglobin threshold for transfusion in coronary artery bypass procedures: effect on patient outcome. Transfusion. 1999;39(10):1070-1077.

44. Hajjar LA, Vincent JL, Galas FR, et al. Transfusion requirements after cardiac surgery: the TRACS randomized controlled trial. JAMA. 2010;304(14):1559-1567.

45. Murphy GJ, Pike K, Rogers CA, et al. Liberal or restrictive transfusion after cardiac surgery. $N$ Engl J Med. 2015;372(11):997-1008.

46. Nakamura RE, Vincent JL, Fukushima JT, et al. A liberal strategy of red blood cell transfusion reduces cardiogenic shock in elderly patients undergoing cardiac surgery. $J$ Thorac Cardiovasc Surg. 2015;150(5):1314-1320.

47. Spinelli E, Bartlett RH. Anemia and transfusion in critical care: physiology and management. J Intensive Care Med. 2014;31(5):295-306.

48. Potter L, Moppett IK. Systematic review and meta-analysis of the influence of anaemia on mortality in hip fracture. Br J Anaesth. 2013;110(5):869-870.

49. Fried LP, Ferrucci L, Darer J, Williamson JD, Anderson G. Untangling the concepts of disability, frailty, and comorbidity: implications for improved targeting and care. J Gerontol A Biol Sci Med Sci. 2004;59(3):255-263.

50. Berry SD, Samelson EJ, Bordes M, Broe K, Kiel DP. Survival of aged nursing home residents with hip fracture. J Gerontol A Biol Sci Med Sci. 2009;64(7):771-777.

51. Pitkala KH, Laurila JV, Strandberg TE, Tilvis RS. Prognostic significance of delirium in frail older people. Dement Geriatr Cogn Disord. 2005;19(2-3):158-163. doi: 10.1159/000082888.

52. Izuel Rami M, Garcia Erce JA, Gomez-Barrera M, Cuenca Espierrez J, Abad Sazatornil R, Rabanaque Hernandez MJ. Relationship between allogeneic blood transfusion, iron deficiency and nosocomial infection in patients with hip fracture. Med Clin (Barc). 2008;131(17):647-652.

53. Saxton A, Velanovich V. Preoperative frailty and quality of life as predictors of postoperative complications. Ann Surg. 2011;253(6):1223-1229.

54. Terekeci HM, Kucukardali Y, Onem Y, et al. Relationship between anaemia and cognitive functions in elderly people. Eur J Intern Med. 2010;21(2):87-90.

55. Foss NB, Kristensen MT, Kehlet H. Anaemia impedes functional mobility after hip fracture surgery. Age Ageing. 2008;37(2):173-178.

56. Gregersen M, Borris LC, Damsgaard EM. Red blood cell transfusion strategies and health care-associated infection. JAMA. 2014;312(19):2041.

57. Halm EA, Wang JJ, Boockvar K, et al. The effect of perioperative anemia on clinical and functional outcomes in patients with hip fracture. J Orthop Trauma. 2004;18(6):369-374.

58. Lawrence VA, Silverstein JH, Cornell JE, Pederson T, Noveck H, Carson $\mathrm{JL}$. Higher $\mathrm{Hb}$ level is associated with better early functional recovery after hip fracture repair. Transfusion. 2003;43(12):1717-1722. 
International Journal of Clinical Transfusion Medicine is an international, peer-reviewed, open access, online journal publishing clinicalexperimental, policy-making and evidence-based practices of all topics pertaining to clinical transfusion medicine. Original research, short reports, reviews, case reports and commentaries are invited.
The manuscript management system is completely online and includes a very quick and fair peer-review system, which is all easy to use. Visit http://www.dovepress.com/testimonials.php to read real quotes from published authors.

Submit your manuscript here: https://www.dovepress.com/international-journal-of-clinical-transfusion-medicine-journal 